\title{
Genome variability of some Gentiana $L$. species in nature and in culture in vitro: RAPD-analysis
}

\author{
M. O. Twardovska, N. M. Drobyk', V. M. Mel'nyk, I. I. Konvalyuk, V. A. Kunakh
}

Institute of Molecular Biology and Genetics NAS of Ukraine

150, Akademika Zabolotnogo Str., Kyiv, Ukraine, 03680

${ }^{1}$ Volodymyr Hnatiuk Ternopil' National Pedagogical University

2, M. Kryvonosa Str., Ternopil', Ukraine, 46027

kunakh@imbg.org.ua

\begin{abstract}
Aim. Investigation of intraspecies and somaclonal variability of $G$. acaulis, G. cruciata and G. punctata. Methods. Random amplified polymorphic DNA-polymerase chain reaction (RAPD-PCR), gel-electrophoresis. Results. It was established a species specificity for indicators of gentians genetic heterogeneity - the proportion of polymorphic amplicons and genetic distances. A level of intraspecies variation decreased in the direction of $G$. acaulis $>G$. punctata $>$ G. cruciata. Changes in gentians tissue culture by the proportion of polymorphic amplicons were shown to vary within the range of 10-15\% and failed to extend beyond the intraspecies variation. Conclusions. Genome variation of G. acaulis, G. cruciata and G. punctata was studied through the use of RAPD-PCR. The gentians were found to be characterized by different variability in both nature and culture in vitro. In the tissue culture there were discovered considerably smaller number changes as compared to intraspecies variation.
\end{abstract}

Keywords: genome variability, Gentiana L. species, plant tissue culture, intraspecies and somaclonal variation, $R A P D-P C R$.

Introduction. Gentiana L. species are valuable medicinal and decorative plants; growing in Ukraine mainly in the Carpathian Mountains. The diminishing of natural habitats of these species, decrease in their amount and violation of structure of their natural populations due to anthropogenic impact are the reasons of including many of them into the Red Data Book of Ukraine [1]. In its turn, it limits their usage as raw material for pharmaceutics. The provision of efficient protection of gentians requires not only thorough study of these species (including their gene pool), but also the application of novel biotechnologies, in particular, obtaining their cell, tissue and organ cultures in vitro [2-4].

(C) Institute of Molecular Biology and Genetics NAS of Ukraine, 2010
A complex genetic investigation of gentians allowed us to determine their interspecies polymorphism by the chromosome numbers, size of ribosomal DNA repeats, and RAPD-spectra [5-8]. $G$. lutea demonstrated the intraspecies variability of 45S rRNA genes [9].

Besides, we evaluated somaclonal variation of tissue cultures of different Gentiana species by cytogenetic analysis and blot-hybridization [9-12]. The results of molecular and genetic research revealed the changes in the Gentian genome in vitro which are in the range of intraspecies variability [9]. In many cases the variability in vitro is not revealed at the DNA level, but is detected while studying karyotype [6, 10-12].

The aim of current work is further study on intraspecies and somaclonal variability of $G$. acaulis, G. cruciata and G. punctata by RAPD-PCR that will 
extend our knowledge of the peculiarities of Gentian genome variability in both nature and culture in vitro.

Materials and Methods. The plants from natural populations were used as material for investigation: G. acaulis (mountains Turkul, Rebra, Brebeneskul, all in Chornogora Ridge, Ukrainian Carpathians), G. cruciata (Krenychi village, Kyiv region and reservation "Medobory", Ternopil' region), G. punctata (mountains Pozhyzhevska and Breskul, Chornogora Ridge, mountain Troyaska, Svydovets Ridge, Ukrainian Carpathians), we also used plants of these species grown in sterile conditions (aseptic plants). Genetic variability of gentians in nature was estimated analysing of eight samples of $G$. acaulis from three populations (four plants - Rebra populations, two - Turkul population, and two - Brebeneskul population), six samples of G. cruciata (three plants from each of two populations - Medobory and Krenychi) and six samples of G. punctata from three populations (three plants from Breskul, two - from Troyaska and one - from Pozhyzhevska). Besides the plants, we used tissue culture of root origin: G. acaulis (Turkul mountain) at $7^{\text {th }}, 30^{\text {th }}$ and $72^{\text {nd }}$ passages, G. cruciata (Krenychi village) at $9^{\text {th }}$ passage, G. cruciata (reservation "Medobory") at $8^{\text {th }}$, G. punctata (Troyaska mountain) at $10^{\text {th }}$ and G. punctata (Pozhyzhevska mountain) at $15^{\text {th }}$ passages of growth, obtained from aseptic plants. One passage of all calluses lasted for four weeks. The conditions of obtaining and growing calluses of the gentians investigated are described in the works $[2,3]$. The variability of tissue culture of these species was compared with a donor plant, which was also used for the analysis of intraspecies polymorphism.

DNA isolation and gel-electrophoresis of amplification products were performed by the methods previously chosen [10]. The conditions of polymerase chain reaction with the random amplified polymorphic DNA and nucleotide sequences of the primers are described in [8].

The results of processing RAPD-products electrophoregrams are presented as a binary matrix, where the presence or absence of similar in size amplicons is indicated as " 1 " or " 0 ", respectively. Genetic distances were calculated according to Nei and Li's model on the basis of composed matrices using
POPGENE 1.31 programme $[13,14]$. The unweighted pair group method with arithmetic mean (UPGMA) was applied to build a dendrogram of relations between investigated objects, using MEGA 3.1 programme [15]. The ratio of polymorphic amplicons (P) was determined by the formula

$$
\mathrm{P}=\frac{\text { Amount of polymorphic amplicons }}{\text { Total amount of amplicons }} \cdot 100 \% \text {. }
$$

Results and Discussion. According to the RAPD-analysis of Gentiana samples with 21 arbitrary primers, 957 fragments of 250-3000 b.p. were obtained. Not all the primers produced clear amplification products, therefore calculations for G. cruciata, G. punctata, and G. acaulis were performed using 21, 19, and 17 primers, respectively. The total amount of clear restored amplicons for G. acaulis was 313 (18.4 per primer on average), G. cruciata - 315 (15 per primer), G. punctata - 329 (17.3 per primer).

Some typical RAPD-spectra for G. acaulis plants are presented in Fig.1, $a$. The percent of polymorphic amplicons (P) in investigated samples out of the total selection of primers was $63 \%$. RAPD-spectra of the donor plant (Turkul mountain) and its tissue culture were similar, but not identical (Fig.1, b). The level of genetic polymorphism between these samples is not high consisting only $12 \%$. The highest similarity was shown for the RAPD-spectra of same callus samples, isolated at $30^{\text {th }}$ and $72^{\text {nd }}$ passages (Fig. $1, b$ ).

The results of RAPD-analysis were used to build a dendrogram of genetic similarity of $G$. acaulis samples (Fig.2). The dendrogram shows that the investigated objects form two clusters. The first cluster consists of the G. acaulis samples originated from the population localised on Rebra Mountain, the second - of the objects from two other populations, namely Turkul and Brebeneskul. The first cluster contains a subcluster, formed by wildling plants from Rebra population, and two separate branches, presented by aseptic plants from the same population. The second cluster divides clearly into two subclusters: one -the samples from Turkul Mountain, the other - plants from Brebeneskul Mountain. The values of genetic distances between specific genotypes of these populations are very close. In their turn, the samples of Turkul population show a 

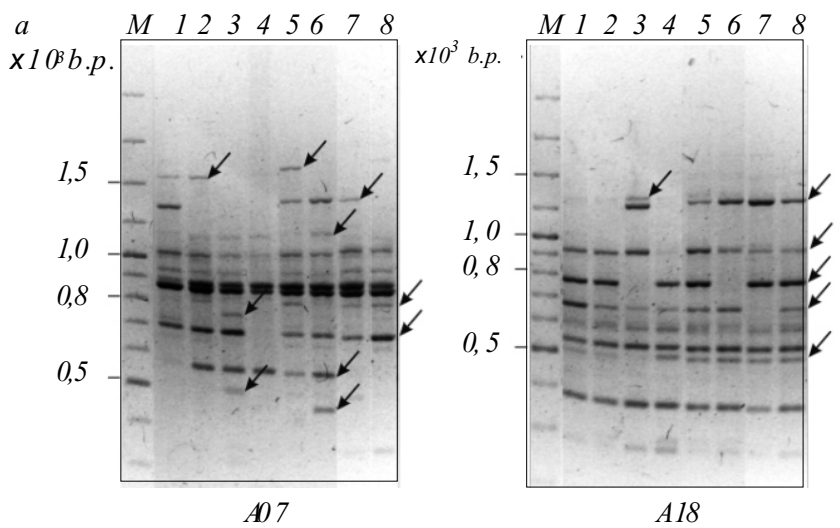

$b$

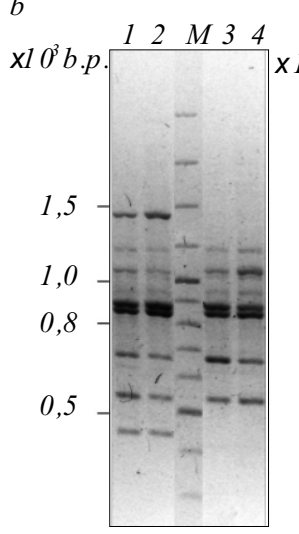

A07

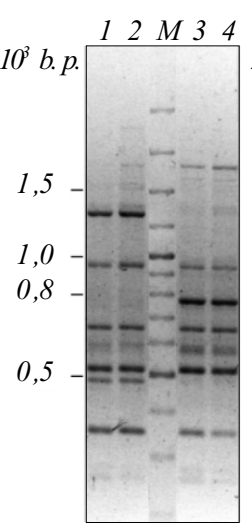

Al 8

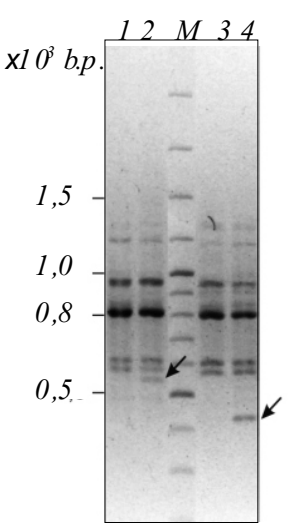

$B 08$
Fig. 1. RAPD-profiles of different genotypes of G. acaulis: $a-$ intraspecies polymorphism (1-4 - Rebra population plants; 5-6Turkul population plants; $7-8-$ Brebeneskul population plants); $b-$ variability of DNA samples of Turkul population plants in culture in vitro $\left(1\right.$ - donor plant; 2 - tissue culture of $7^{\text {th }}$ passage, obtained from plant $1 ; 3,4-$ tissue culture of $30^{\text {th }}$ and $72^{\text {nd }}$ passages respectively). $M$ - marker of molecular masses. The arrows indicate polymorphic amplicons for all the lines $(a)$ or for lines 1, 2 and 3, 4 respectively $(b)$. The names of primers used are indicated under electrophoregrams

separate branch, presented by a wildling plant, and two subclusters, the first of which is formed by a donor plant and a tissue culture of $7^{\text {th }}$ passage, isolated from it, and the second one - by the callus of $30^{\text {th }}$ and $72^{\text {nd }}$ passages from another plant, which was not studied in the current work. The dendrogram shows (Fig.2) - it is samples of callus, cultivated for a long time that have the highest level of genetic proximity. The results presented show a higher genetic proximity of G. acaulis samples from Turkul and Brebeneskul populations, which form one cluster of the

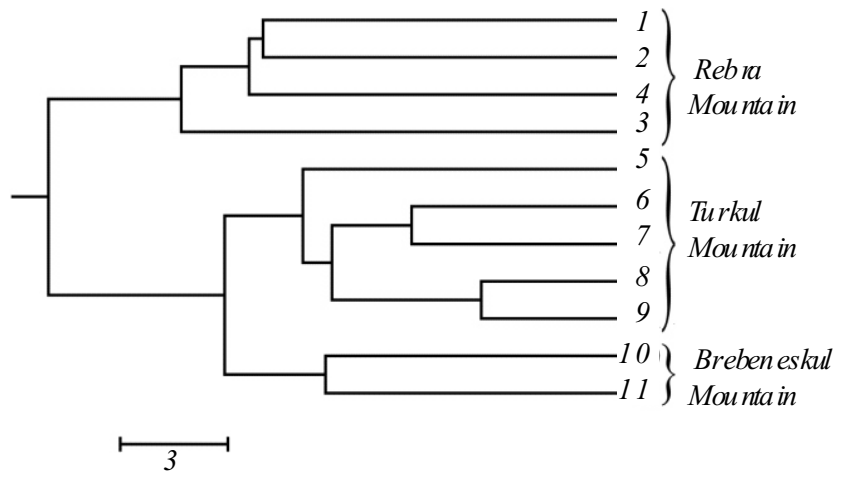

Fig. 2. Dendrogram of genetic similarity of G. acaulis samples, built using UPGMA method by genetic distances of Nei and Li [14]: 1, 2 - wildling and 3,4-aseptic plants; 5 - wildling plant; 6 aseptic donor plant; 7 - tissue culture of $7^{\text {th }}$ passage, obtained from plant $6 ; 8,9-$ tissue culture of $30^{\text {th }}$ and $72^{\text {nd }}$ passage respectively; 10,11 - wildling plants

dendrogram, and remoteness of Rebra samples as they form a separate cluster.

According to Nei and $\mathrm{Li}$ the genetic distance between $G$. acaulis plants is in the range of $0.170-0.438$ (Table 1). These indices are in the range of values of interspecies variability, previously obtained by us (the average value of genetic distances between seven species is 0.54 ), and genetic distance between G. acaulis and G. verna (0.532), the closest in the dendrogram [8]. The level of genetic differences between the callus of $G$. acaulis (Turkul Mountain) of $7^{\text {th }}$ passage and the donor plant is 0.122 which is in the range of genetic distances between the plants of these species.

For the investigated G. cruciata plants P equals $30 \%$. The comparison of RAPD-spectra of donor plants and their tissue cultures, (Fig.3), revealed that the levels of genetic polymorphism between them are $10 \%$ and $12 \%$ for Medobory and Krenychi populations, respectively.

The results of RAPD-analysis were used to build the dendrogram of genetic similarity of $G$. cruciata samples (Fig.4), which were divided into two clusters according to the population. The first cluster, presented by the samples from Krenychi population, has two separate subclusters, formed by wildling and aseptic plants respectively, and one more plant from nature and tissue culture from an aseptic plant. The second cluster 
Table 1

Genetic distances by Nei and Li [14] between G. acaulis samples following RAPD-analysis

\begin{tabular}{|c|c|c|c|c|c|c|c|c|c|c|c|}
\hline \multirow{3}{*}{ Sample } & \multicolumn{4}{|c|}{ Rebra Mountain } & \multicolumn{5}{|c|}{ Turkul Mountain } & \multirow{2}{*}{\multicolumn{2}{|c|}{$\begin{array}{c}\begin{array}{c}\text { Brebeneskul } \\
\text { Mountain }\end{array} \\
\text { Wildling plant }\end{array}$}} \\
\hline & \multicolumn{2}{|c|}{ Wildling plant } & \multicolumn{2}{|c|}{ Aseptic plant } & \multirow{2}{*}{$\begin{array}{c}\begin{array}{c}\text { Wildling } \\
\text { plant }\end{array} \\
5\end{array}$} & \multirow{2}{*}{$\begin{array}{c}\begin{array}{c}\text { Aseptic } \\
\text { donor plant }\end{array} \\
6\end{array}$} & \multirow{2}{*}{$\begin{array}{c}\text { Tissue culture of } \\
\text { 7th passage from } \\
\text { plant } 6\end{array}$} & \multirow{2}{*}{$\begin{array}{c}\begin{array}{c}\text { Tissue culture } \\
\text { of } 30 \text { th } \\
\text { passage }\end{array} \\
8\end{array}$} & \multirow{2}{*}{$\begin{array}{c}\begin{array}{c}\text { Tissue culture } \\
\text { of } 72 \mathrm{nd} \\
\text { passage }\end{array} \\
9 \\
\end{array}$} & & \\
\hline & 1 & 2 & 3 & 4 & & & & & & 10 & 11 \\
\hline 1 & - & & & & & & & & & & \\
\hline 3 & 0,274 & 0,249 & - & & & & & & & & \\
\hline 4 & 0,217 & 0,209 & 0,229 & - & & & & & & & \\
\hline 5 & 0,308 & 0,282 & 0,376 & 0,287 & - & & & & & & \\
\hline 8 & 0,295 & 0,253 & 0,344 & 0,274 & 0,163 & 0,170 & 0,148 & - & & & \\
\hline 9 & 0,308 & 0,300 & 0,376 & 0,295 & 0,182 & 0,174 & 0,174 & 0,083 & - & & \\
\hline 10 & 0,300 & 0,326 & 0,404 & 0,313 & 0,174 & 0,205 & 0,229 & 0,186 & 0,229 & - & \\
\hline
\end{tabular}

has samples from Medobory population, distributed in a different way: two plants belong to one subcluster, while aseptic plant and its tissue culture form separate branches. The dendrogram demonstrates that in both cases the donor plants and their calluses do not belong to any cluster, which may testify to some changes in the genome in G. cruciata tissue culture. The highest level of genetic proximity was demonstrated by two plants from Medobory population.

According to Nei and $\mathrm{Li}$, the values of genetic distances between G. cruciata plants (Table 2) are in the range of 0.046 to 0.215 , which is in good agreement with the previously determined index of interspecies variability of gentians (0.54), as well as genetic distance to the species, which is the closest in the dendrogram - G. pneumonanthe (0.498) [8]. The comparison of the tissue culture and primary plant from Krenychi and Medobory populations revealed that genetic distance between them is 0.132 and 0.1 , respectively.

Some typical RAPD-spectra for G. punctata plants are presented in Fig.5. The percentage of polymorphic amplicons in investigated G. punctata plants is 39\%. According to this index, the level of genetic polymorphism between the primary plant of Pozhyzhevska and Troyaska populations and their tissue culture is relatively low, amounting to $11 \%$ and $15 \%$ respectively.

The results of RAPD-analysis were used to build a dendrogram of genetic similarity between investigated G. punctata samples (Fig.6), forming two clusters. The first one comprises G. punctata objects (Troyaska Mountain), while the second one has representatives of two other populations of this species - Breskul and Pozhyzhevska populations. The second cluster may be divided into two subclusters: one is formed by three plants from Breskul Mountain, and the second one consists of the samples from Pozhyzhevska Mountain. It means that in the dendrogram of genetic similarity the division of G. punctata objects corresponds to their belonging to a specific population. Two plants of Breskul population demonstrated the highest genetic proximity.

According to Nei and $\mathrm{Li}$, the genetic distance between $G$. punctata plants is in the range of 0.063 to 0.255 (Table 3 ). These values do not exceed the average index of interspecies variability (0.54), previously obtained by us, and the distance between 
Table 3

Genetic distances by Nei and Li [14] between G. punctata samples following RAPD-analysis

\begin{tabular}{c|c|c|c|c|c|c|c}
\hline \multirow{3}{*}{ Sample } & \multicolumn{3}{|c|}{ Troyaska Mountain } & \multicolumn{2}{c|}{ Breskul Mountain } & \multicolumn{2}{c}{ Pozhyzhevska Mountain } \\
\cline { 2 - 9 } & Aseptic donor plant & $\begin{array}{c}\text { Tissue culture of } 10^{\text {th }} \\
\text { passage from plant } 1\end{array}$ & Wildling plant & \multicolumn{2}{c}{ Wildling plant } & $\begin{array}{c}\text { Wildling } \\
\text { plant }\end{array}$ & $\begin{array}{c}\text { Tissue culture of } \\
15^{\text {th }} \text { passage }\end{array}$ \\
\cline { 2 - 9 } & 1 & 2 & 3 & 4 & 5 & 6 & 7 \\
\hline
\end{tabular}

\begin{tabular}{|c|c|c|c|c|c|c|c|c|}
\hline 1 & - & & & & & & & \\
\hline 2 & 0,158 & - & & & & & & \\
\hline 3 & 0,161 & 0,147 & - & & & & & \\
\hline 4 & 0,243 & 0,198 & 0,224 & - & & & & \\
\hline 5 & 0,224 & 0,201 & 0,228 & 0,113 & - & & & \\
\hline 6 & 0,255 & 0,216 & 0,235 & 0,126 & 0,063 & - & & \\
\hline 7 & 0,239 & 0,201 & 0,213 & 0,228 & 0,158 & 0,137 & - & \\
\hline 8 & 0,228 & 0,213 & 0,224 & 0,255 & 0,183 & 0,190 & 0,113 & - \\
\hline
\end{tabular}

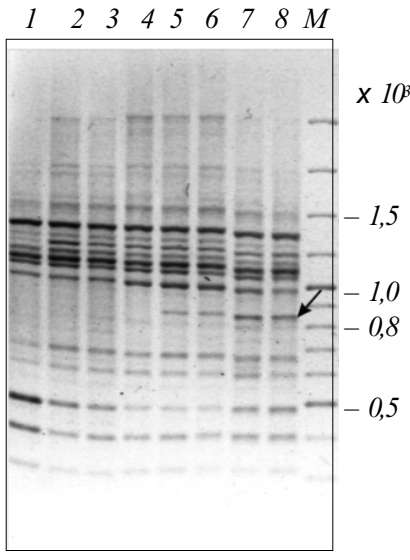

A04

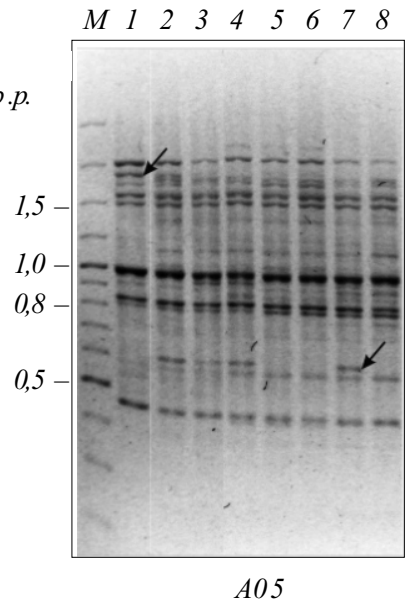

A05
Fig. 5. Products of DNA amplification of G. punctata samples from Troyaska Mountain ( 1 - aseptic donor plant; 2 - tissue culture of $10^{\text {th }}$ passage, obtained from plant $1 ; 3$ - wildling plant), from Breskul Mountain (4, 5, 6 - wildling plants) and from Pozhyzhevska Mountain ( 7 - wildling plant; 8 - tissue culture of $15^{\text {th }}$ passage); $M$ - marker of molecular masses. The arrows indicate polymorphic amplicons. The names of primers used are indicated under electrophoregrams

genus, close to Gentiana, revealed positive correlation between genome variability and sizes of populations [19]. There is an assumption that growth in extreme conditions may cause increase in genetic heterogeneity which ensures survival of a species [16]. In particular, the authors explain high level of genome polymorphism in Ungernia victoris Vved. Ex Artjushenko by growth in severe conditions and narrow areal of this endemic species [20].

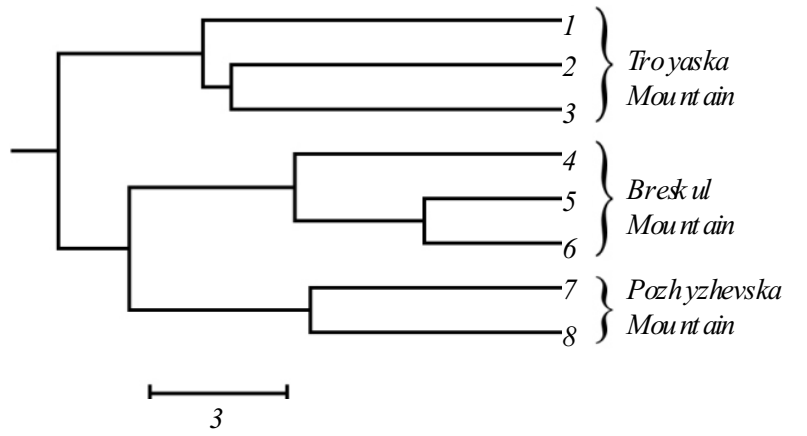

Fig. 6. Dendrogram of genetic similarity of G. punctata samples, built using UPGMA method by genetic distances of Nei and Li [14]: 1 - aseptic donor plant; 2 - tissue culture of $10^{\text {th }}$ passage, obtained from plant $1 ; 3$-wildling plant; $4-6$ - wildling plants; 7 -wildling plant; 8 - tissue culture of $15^{\text {th }}$ passage

Literature data on the impact of geographic location of a species on the level of genetic variability are ambiguous. For instance, the level of genome variability of populations of Orobanche gracilis Sm. (var. gracilis) depends on their location and is higher in the northern regions of Spain comparing to the southern ones [18]. However, RAPD-analysis of polymorphism of representatives of Lemnaceae family did not reveal any connection between intraspecies differentiation and geographic location of samples. The authors explain this fact by the absence of territorial isolation of specific populations [21].

Generally, the grouping of investigated objects on dendrograms of genetic similarity corresponds to their 
belonging to a specific population. At the same time, noteworthy are the results of investigation of G. acaulis and G. punctata plants from three populations, located at different distance from each other. Clusterization of G. punctata samples from three populations on the dendrogram reflects geographic location of these populations. The objects from Pozhyzhevska and Breskul mountains (two neighbouring peaks of Chornogora Ridge) are distributed on the dendrogram of genetic similarity in the boundaries of one cluster, whereas the samples from Troyaska population, which is much farther from two former ones (Svydovets Ridge), form a separate cluster. However, it is not possible to explain the data on $G$. acaulis, by geographic location only.

The results demonstrate high level of genetic similarity between the species of Turkul and Brebeneskul populations, which form one cluster on the dendrogram, while the Rebra samples, forming a separate cluster, are much farther from them, though Turkul Mountain is geographically closer to Rebra Mountain than to Brebeneskul Mountain. It is likely conditioned by genetic isolation of the mentioned populations, maybe due to the biological specificities of $G$. acaulis, which has the highest capability of vegetative reproduction among the investigated species [22]. The similar regularity was revealed while studying these plants from other mountain ridges of Europe, in different parts of the Alps and the Pyrenees [23]. In particular, G. acaulis samples from the same mountain ridge, the Maritime Alps, are located in different clades of the dendrogram according to the results of RAPD-analysis. The authors also revealed considerable genetic distance between the populations of $G$. clusii, one more representative of Ciminalis section, a species, which is very close by its biological properties to G. acaulis .

Taking into account our own and literature data we assume that the biological specificities of G. acaulis are a genuine reason of partial genetic distinguishing of the investigated populations and certain genotypes in the boundaries of one locality.

The level of somaclonal variation by $\mathrm{P}$ for all the investigated species is 2-5 times lower than intraspecies polymorphism and fluctuates in the range of $10-15 \%$. The same tendency was revealed while studying the genome variability of $U$. victoris tissue culture: the authors found out that it is much lower in tissue culture than intraspecies variability [24, 25]. The level of somaclonal variability was in the range of intraspecies variability in the investigation of tissue culture and intact plants of some Iris L. genus plants [26]. However, it is known that in vitro cultivation may cause considerable genome rearrangements, the scope of which in Rauwolfia serpentina is comparable with the interspecies rearrangements [27] and in Panax ginseng - with intraspecies rearrangements [28].

The selection of $G$. acaulis objects demonstrated the highest level of genetic proximity for the callus samples, isolated at $30^{\text {th }}$ and $72^{\text {nd }}$ passages of cultivation. It may testify to relative genetic stability of the mentioned callus during the third-sixth years of in vitro cultivation. This assumption seems to be proven by the results of cytogenetic investigations which demonstrated that with age the ratio of polyploid cells in this tissue culture increases, but the level of aneuploid cells in six-year-old callus does not change significantly in comparison with one-year-old one [29]. Preservation of relative genetic stability during long-term cultivation was also revealed in the study on $45 \mathrm{~S}$ rDNA in the tissue culture of $23^{\text {rd }}-50^{\text {th }}$ passages (2-5 years of in vitro cultivation) of another Gentian species $-G$. lutea [9].

Conclusions. RAPD-PCR method was applied to study genome variability of G. acaulis, G. punctata and G. cruciata. It was shown that gentians are notable for different level of genetic heterogeneity in both nature and culture in vitro. The content of polymorphic amplicons, characterizing the level of intraspecies variability, is as follows: G. acaulis $-63 \%$, G. punctata $-39 \%$ and G. cruciata - 30\%. Clusterization of the objects on dendrograms corresponds to their belonging to a specific population which testifies to relative genetic isolation of populations (localities). The level of somaclonal variation by $\mathrm{P}$ for all the investigated species is 2-5 times lower than that of intraspecies polymorphism, and is in the range of $10-15 \%$.

The authors would like to express their sincere gratitude to I. O. Andreev, K. V. Spiridonova, and O. M. Bublyk for their help and consultations while obtaining and analyzing the results. 
М. О. Твардовська, Н. М. Дробик ${ }^{1}$, В. М. Мельник, I. І. Конвалюк, B. А. Кунах

Геномна мінливість деяких видів роду Gentiana L.

у природі та в культурі in vitro: RAPD-аналіз

Інститут молекулярної біології і генетики НАН України

Вул. Академіка Заболотного, 150, Київ, Україна, 03680

${ }^{1}$ Тернопільський національний педагогічний університет ім. В. Гнатюка Вул. М. Кривоноса, 2, Тернопіль, Україна, 46027

Резюме

Мета. Дослідити внутрішньовидову та сомаклональну мінливість Gentiana acaulis, G. cruciata ma G. punctata. Memoди. Полімеразна ланцюгова реакиія з праймерами довільної послідовності (RAPD- ПЛP), гель-електрофорез. Результати. Виявлено видоспеиифічність показників генетичної гетерогенності тирличів - відсотка поліморфних ампліконів і генетичних відстаней. Рівень внутрішньовидової мінливості зменшується у напрямку $G$. acaulis $>$ G. punctata $>$ G. cruciata. Показано, щяо зміни в культурі тканин тирличів за вмістом поліморфних ампліконів лежать у діапазоні 10- $15 \%$ і не виходять за межі внутрішньовидової варіабельності. Висновки. Методом RAPD-ПЛР досліджено геномну мінливість G. acaulis, G. cruciata ma G. punctata. Встановлено, щяо тирличi характеризуються різною варіабельністю як у природі, так $i$ в культурі in vitro. У культурі тканин виявлено зміни, які значно менші порівняно з внутрішньовидовою мінливістю.

Ключові слова: геномна мінливість, види роду Тирлич (Gentiana L.), культура тканин рослин, внут рішньовидова і сомаклональна варіабельність, RAPD-ПЛР.

М. О. Твардовская, Н. М. Дробык, В. Н. Мельник,

И. И. Конвалюк, В. А. Кунах

Геномная изменчивость некоторых видов рода Gentiana L. в природе и в культуре in vitro: RAPD-анализ

Резюме

Цель. Исследовать внутривидовую и сомаклональную изменчивость Gentiana acaulis, G. cruciata u G. punctata. Memodb. Полимеразная цепная реакиия с праймерами произвольной последовательности (RAPD-ПЦР), гель-электрофорез. Результаты. Обнаружена видоспецифичность показателей генетической гетерогенности горечавок - процента полиморфных ампликонов и генетических расстояний. Уровень внутривидовой изменчивости уменьшается в ряду G. acaulis $>$ G. punctata $>$ G. cruciata. Показано, что изменения в культуре тканей горечавок по содержанию полиморфных ампликонов лежат в диапазоне 10$15 \%$ и не выходят за границы внутривидовой вариабельности. Bыводы. Методом RAPD-ПЦР исследована геномная изменчивость G. acaulis, G. cruciata u G. punctata. Установлено, что горечавки характеризуются различной вариабельностью как в природе, так и в культуре in vitro. В культуре тканей обнаружены значительно меньшие изменения по сравнению с внутривидовой изменчивостью.

Ключевые слова: геномная изменчивость, виды рода Горечавка (Gentiana L.), культура тканей растений, внутривидовая и сомаклональная вариабельность, RAPD-ПЦР.

\section{REFERENCES}

1. Red data Book of Ukraine. Plants and Fungy / 2 ed.-Kyiv: M. Bazhan Ukr. encyclopedy, 1996.-608 p.

2. Strashniuk N. M., Hrytsak L. R., Les'kova O. M., Mel'nyk V. $M$. Introduction in culture in vitro of some Gentiana L. genus species // Physiol. and Biochem. of Cultivated Plants.-2004.36, N 4.-P. 327-334.

3. Strashniuk N. M., Twardovska M. O., Mel'nyk V. M. Introduction in culture in vitro of Gentiana cruciata L. and Gentiana pneumonanthe L. species // Nauk. zap., Ser. Biol. (Ternop. nats. pedagog. univ. im. Volodymyra Gnatuka).-2006.-N 2 (29).-P. 100-107.

4. Pat. of Ukraine on a useful model N 36436 dated by 27.10. 2008. Method to gain of non- transgenic root isolated culture of gentians (Gentiana L.) / N. M. Strashniuk, L. R. Hrytsak, V. M. Mel'nyk, M. O. Twardovska, I. I. Konvalyuk, V. A. Kunakh // Bull. N 20.

5. Mel'nyk V. M., Andreev I. O., Spiridonova K. V., Kunakh V. A. Restriction mapping and variability of $18 \mathrm{~S}-25 \mathrm{~S}$ ribosomal genes in some species of Gentiana genus // Cytology and Genetics.-2003.-37, N 5.-P. 65-71.

6. Andreev I. O., Spiridonova K. V., Mel'nyk V. M., Kunakh V. $A$. Interspecies polymorphism and rearrangements in culture in vitro of 5S rRNA genes in Gentiana L. species // Repts Nat. Acad. Sci. Ukr.-2004.-N 6.-P. 189-192.

7. Strashniuk N. M., Twardovska M. O., Mel'nyk V. M. Karyology of some European species of Gentiana L. (Gentianaceae) // Ukr. Bot. Zhur.-2008.-65, N 6.-P. 836-848.

8. Twardovska M. O., Strashniuk N. M., Mel'nyk V. M., Konvalyuk I. I., Kunakh V. A. RAPD-analysis of the genome polymorphism for some Gentiana L. species from the Ukrainian flora // Repts Nat. Acad. Sci. Ukr.-2009.-N 5.-P. 200-204.

9. Mel'nyk V. M., Spiridonova K. V., Andreev I. O., Strashniuk N. M., Kunakh V. A. Variability of nuclear $18 \mathrm{~S}-25 \mathrm{~S}$ rDNA of Gentiana lutea L. in nature and in tissue culture in vitro // Cytology and Genetics.-2004.-38, N 3.-P. 16-21.

10. Mel'nyk V. M., Andreev I. O., Spiridonova K. V., Strashniuk N. M., Kunakh V.A.18S-25S rDNA variation in tissue culture of some Gentiana L. species // Cytology and Genetics.-2007.-41, N 2.-P. 19-23.

11. Twardovska M. O., Strashniuk N. M., Mel'nyk V. M., Kunakh $V$. A. Evaluation of some Gentiana L. species tissue culture genetic variation // Bull. of Vavilov Soc. Geneticists and Breeders of Ukr.-2007.-5, N 1-2.-P. 104-111.

12. Twardovska M. O., Strashniuk N. M., Mel'nyk V. M., Adonin V. I., Kunakh V. A. Chromosomal variability in a tissue culture of rare species of the genus Gentiana L. // Cytology and Genetics.-2008.-42, N 4.-P. 12-17.

13. Yeh F. C., Rongcai Y., Boyle T. POPGENE. Version 1.31.Edmonton: Univ. Alberta, 1999.

14. Nei M., Li W.-H. Mathematical model for studying genetic variation in terms of restriction endonucleases // Proc. Nat. Acad. Sci. USA.-1979.-76, N 10.-P. 5269-5273.

15. Kumar S., Tamura K., Nei M. MEGA3: Integrated software for molecular evolution genetics analysis and sequences alignment // Briefin. Bioinf.-2004.-5,N 2.-P. 150-163.

16. Nevo E. E. Evolution of genome-phenome diversity under environmental stress // Proc. Nat. Acad. Sci. USA.-2001.98, N 11.-P. 6233-6240. 
17. Ward S. Genetic analysis of invasive plant populations at different spatial scales // Biol. Invas.-2006.-8, N 3.-P. 541552.

18. Roman B., Hernandez R., Pujadas-Salva A. J., Cubero J. I., Rubiales D., Satovic Z. Genetic diversity in two variants of Orobanche gracilis Sm. [var. gracilis and var. deludens (Beck) A. Pujadas] (Orobanchaceae) from different regions of Spain // Electron. J. Biotechnol.-2007.-10, N 2.-P. 221-229.

19. Fisher M., Matthies D. RAPD variation in relation to population size and plant fitness in the rare Gentianella germanica (Gentianaceae) // Am. J. Bot.-1998.-85, N 6.-P. 811-819.

20. Bublyk O. M., Andreev I. O., Spiridonova K. V., Muzyka V. I., Kolonina I. V., Kunakh V. A. Genetic heterogeneity of the rare endemic species Ungernia victoris (Amaryllidaceae): RAPD-analysis // Ukr. Bot. Zhur.-2008.-65, N 3.-P. 445452.

21. Martirosyan E. V., Ryzhova N. N., Skryabin K. G., Kochieva E. Z. RAPD analysis of genome polymorphism in the family Lemnaceae // Russ. J. Genet.-2008.-44, N 3.-P. 417-422.

22. Serebryakova T. I. Models of shoot formation and some evolutionary trends in the genus Gentiana L. // Bull. MOIP Sect. Biol.-1979.-84, N 6.-P. 97-109.

23. Hungerer K. B., Kadereit J. W. The phylogeny and biogeography of Gentiana L. sect. Ciminalis (Adans.) Dumort.: A historical interpretation of distribution ranges in the European high mountains // Persp. Plant Ecol., Evol. and System.1998.-1, N 1.-P. 121-135.

24. Bublyk O. M., Andreev I. O., Spiridonova K. V., Mozhylevska L. P., Kunakh V.A. Studies on the genome variability in
Ungernia victoris tissue culture through RAPD-markers // Bull. of Vavilov Soc. Geneticists and Breeders of Ukr.2006.-4, N 1.-P. 3-11.

25. Bublyk O. M., Andreev I. O., Spiridonova K. V., Kunakh V. A. Somaclonal variability of Ungernia victoris: the necessity of comprehensive genetic analysis // Biopolym. cell.-2008.-24, N 6.-P. 487-493.

26. Kozyrenko M. M., Artyukova E. V., Lauve L. S., Boltenkov E. $V$. The analysis of genetic variability of callus cultures of several species of Iris L. genus // Russ. J. Biotechnol.-2002.N 4.-P. 38-48.

27. Solov'yan V. T., Spiridonova K. V., Kunakh V. A. Genome rearrangements in cell culture of Rauwolfia serpentina: Diverse pattern of genome variations // Russ. J. Genet.-1994.-30, N 2.-P. 250-254.

28. Kozyrenko M. M., Artyukova E. V., Lauve L. S., Zhuravlev Yu. $N$., Reunova G. D. The genetic variability of Panax ginseng callus lines // Russ. J. Biotechnol.-2001.-N 1.-P. 19-26.

29. Twardovska M. O., Strashniuk N. M., Mel'nyk V. M., Adonin V. I., Kunakh V. A. Chromosome number variability and chromosome aberration level in Gentiana acaulis L. tissue culture // Bull. of Vavilov Soc. Geneticists and Breeders of Ukr.-2006.-4, N 2.-P. 204-209.

UDC 575.22: 582.923.1 + 576.5 Received 28.07.09 